\title{
Benthic response to chronic natural physical disturbance by glacial sedimentation in an Arctic fjord
}

\author{
Maria Wlodarska-Kowalczuk ${ }^{1, *}$, Thomas H. Pearson ${ }^{2}$, Michael A. Kendall ${ }^{3}$ \\ ${ }^{1}$ Institute of Oceanology, Polish Academy of Science, Powstancow Warszawy 55, 81-712 Sopot, Poland \\ ${ }^{2}$ Akvaplan-niva a.s. Polar Environment Centre, 9296 Tromsø, Norway \\ ${ }^{3}$ Plymouth Marine Laboratory, Prospect Place, Plymouth PL1 3DH, UK
}

\begin{abstract}
The activity of Arctic tidal glaciers results in high turbidity, high rate of inorganic particulate sedimentation and sedimentary instability in near-glacier marine basins. The chronic physical disturbance of sediments is accompanied by low input levels of organic matter. The response of soft-bottom macrofauna to glacial disturbance was studied in Kongsfjord, Svalbard. The quantitative characteristics of the macrofauna of 4 associations located along a gradient of glacier-induced disturbance were examined. Benthic biomass decreased with increased proximity to the glacier (from $10.9 \mathrm{~g}$ wet weight (ww) $\mathrm{m}^{-2}$ in the outermost association to $2.7 \mathrm{~g} \mathrm{ww} \mathrm{m}^{-2}$ in the glacial bay). Faunal density was highest in the transitional zone $\left(592\right.$ ind. $0.1 \mathrm{~m}^{-2}$ ) between the central basin (425 ind. $0.1 \mathrm{~m}^{-2}$ ) and the inner glacial bay (442 ind. $0.1 \mathrm{~m}^{-2}$ ). The average individual biomass was lowest in the glacial bay as a result of the smaller body size of organisms. A decrease in the size of organisms in disturbed sites was not accompanied by a classical shift from 'equilibrium' to 'opportunistic' species. The functional structure of the faunal associations was simplified in the impoverished glacial bay association where 1 guild, the mobile surface-detritus feeders, strongly dominated. Average species number per sample was lowest in the glacial bay ( 22 species) and highest in the transitional association (42 species). Species diversity expressed by the Shannon-Wiener and Hurlbert rarefaction indices and evenness expressed by the Pielou index was lower in the glacial bay than in the remaining associations. The decrease in biomass, mean size of organisms, species diversity and evenness as well as the peaked distribution (i.e. maximum in the transitional zone) of density and species richness are consistent with patterns reported in studies of different natural and anthropogenic disturbances. Some distinct features of the case of glacial-induced disturbance include relatively high taxonomic distinctness and low beta diversity and low faunal dispersion in the near-glacier association.
\end{abstract}

KEY WORDS: Disturbance - Soft sediment communities - Species diversity - Beta diversity · Taxonomic distinctness $\cdot$ Functional groups $\cdot$ Biomass $\cdot$ Arctic

Resale or republication not permitted without written consent of the publisher

\section{INTRODUCTION}

Disturbance is regarded as an important determinant of biotic spatial and temporal patterns (Huston 1994), although the term has been used for many different processes and factors affecting biotic communities. It covers biotic or abiotic processes of natural or anthropogenic origin that affect only the biota or destroy habitats in episodic events or by prolonged stresses (Mackey \& Currie 2001). The effects of disturbance of anthropogenic origin on marine benthic organisms have been described for cases of organic pollution (Pearson \& Rosenberg 1978), mine tailings disposal (Olsgard \& Hasle 1993), heavy metal pollution (Stark 1998), mechanical disturbance of sediments by fish and shrimp trawling (Kaiser et al. 2000), dredge spoils dumping (Rhoads et al. 1978) and ballast water disposal (Blanchard et al. 2003). Natural disturbances that affect benthic communities include both largescale phenomena, such as storms (Hall 1994), tidally induced sand movement, unusually low temperatures and salinities, hypoxia (Santos \& Simon 1980), deposi- 
tion of fluvial sediments (Aller \& Stupakof 1996) and small-scale biologically mediated events such as bioturbation (Hall 1994). These natural phenomena can influence benthic communities already disturbed by anthropogenic impacts in coastal waters of highly populated temperate latitudes, thus making the assessment of the causes of community disturbance uncertain. Causal relationships between natural disturbance processes and accompanying ecological patterns can be more easily understood in polar regions where anthropogenic impacts are relatively low and some areas are still among the most pristine in the world (Clarke \& Harris 2003).

Tidal glaciers, usually situated in the inner parts of Arctic fjords, discharge meltwaters loaded with high levels of particulate mineral material, much of which sediments to the bottom in inner fjord areas (i.e. glacial bays). The animals dwelling in glacial bays are exposed to chronic physical disturbance (Gorlich et al. 1987, Syvitski et al. 1989). High sedimentation results in the formation of unconsolidated, easily eroded sediments, which are readily and frequently resuspended and redeposited (Syvitski et al. 1987). Bottom-dwelling organisms may be buried, larval settlement may be hindered, filtering appendages of suspension feeders may become clogged by inorganic particles and the tubes of tube-building organisms may be buried thereby impeding irrigation and leading to suffocation (Moore 1977, Hall 1994). In addition, the infauna must tolerate episodic catastrophic events such as iceberg scouring, sediment slides and gravity flows (Dowdeswell 1987). Moreover, the high turbidity reduces primary production in the water column, and organic matter sedimenting to the bottom is diluted by the high inorganic sediment load (Gorlich et al. 1987). These processes (high turbidity, high inorganic sedimentation rate, high instability of sediments and low amount of organic matter) are interconnected, and separation of their effects on benthic communities is difficult. However, as clear disturbance effects can be delineated, a 'glacier-induced disturbance' or complex of stress-generating factors can be ascertained. They originate primarily from the tidal glacier activity (meltwater discharge) with intensity decreasing with distance from the glacier front.

The increase of input of terrigenous mineral material to the oceans is one of the predicted climate change consequences. Glacial retreat, currently observed both in Arctic and in the Antarctic, is accompanied by an increase in meltwater outflow and a flux of inorganic particles to the sea (Svendsen et al. 1996). Wheatcroft (2000) predicted that the supply of fluvial waters and sediment material into the ocean will increase in the future due to both human land exploitation and climate warming, resulting in an increase in precipita- tion. Increased sediment loads to coastal waters may also result from such human activities as deforestation, dredging, industrial and domestic discharges, construction activities and aquaculture (Airoldi 2003) and can be regarded as one of the major threats to marine biodiversity (Thrush et al. 2004).

The gradient of glacier-induced disturbance is mirrored by a succession of faunal associations, which was described for Kongsfjord, Spitsbergen by WlodarskaKowalczuk \& Pearson (2004). Our objective in this paper is to quantify faunal density and biomass, species dispersion and diversity and the trophic structure of the biota along the disturbance gradient resulting from glacial sedimentation. Writing on disturbance and diversity relationships, Rosenzweig (1995) noted that 'the processes that produce the patterns will work regardless of the source of the disturbance'. We will compare the patterns found in soft-bottom macrobenthic communities exposed to glacier-induced disturbance to published cases of alternative natural and anthropogenic disturbances to find the common effects, irrespective of the disturbance agents.

\section{MATERIALS AND METHODS}

Study area. Kongsfjord is a $26 \mathrm{~km}$ long open (i.e. no sill at entrance) fjord situated on the western coast of Spitsbergen at $79^{\circ} \mathrm{N}, 12^{\circ} \mathrm{E}$ (Fig. 1). The maximum depth is $\sim 350 \mathrm{~m}$. Three large tidal glaciers terminate in the fjord waters: Kongsbreen, Conwaybreen and Blomstrandbreen. Small icebergs are observed throughout the fjord year round. Large icebergs (up to $10 \mathrm{~m}$ high) circulate or stay anchored in the inner basin. The main water masses of the Kongsfjord include Surface Waters originating from glacier meltwater outflows, Transformed Atlantic Waters originating on the Spitsbergen shelf, Local Fjordic Waters and Winter Bottom Waters formed by a process of deep convection in the winter (Svendsen et al. 2002).

In Kongsbreen glacial bay very high concentrations of suspended inorganic particles in the water (300 to $500 \mathrm{mg} \mathrm{dm}^{3}$ ) and very high inorganic sedimentation rates in the water column (over $800 \mathrm{~g} \mathrm{~m}^{-2} \mathrm{~d}^{-1}$, Zajaczkowski 2000) have been recorded. In the central part of the fjord the concentration of inorganic suspensions in the water decreases to $20 \mathrm{mg} \mathrm{dm}^{-3}$ and the sedimentation rate in the water column to below $25 \mathrm{~g} \mathrm{~m}^{-2} \mathrm{~d}^{-1}$ (Zajaczkowski 2000).

The sediments in the deeper sublittoral of the Kongsfjord (below 30 to $40 \mathrm{~m}$ ) are of fairly uniform mud (Wlodarska-Kowalczuk \& Pearson 2004). The sediment accumulation rate follows the gradient of sedimentation rates in the water column, decreasing by about one order of magnitude from the Kongsbreen glacial 


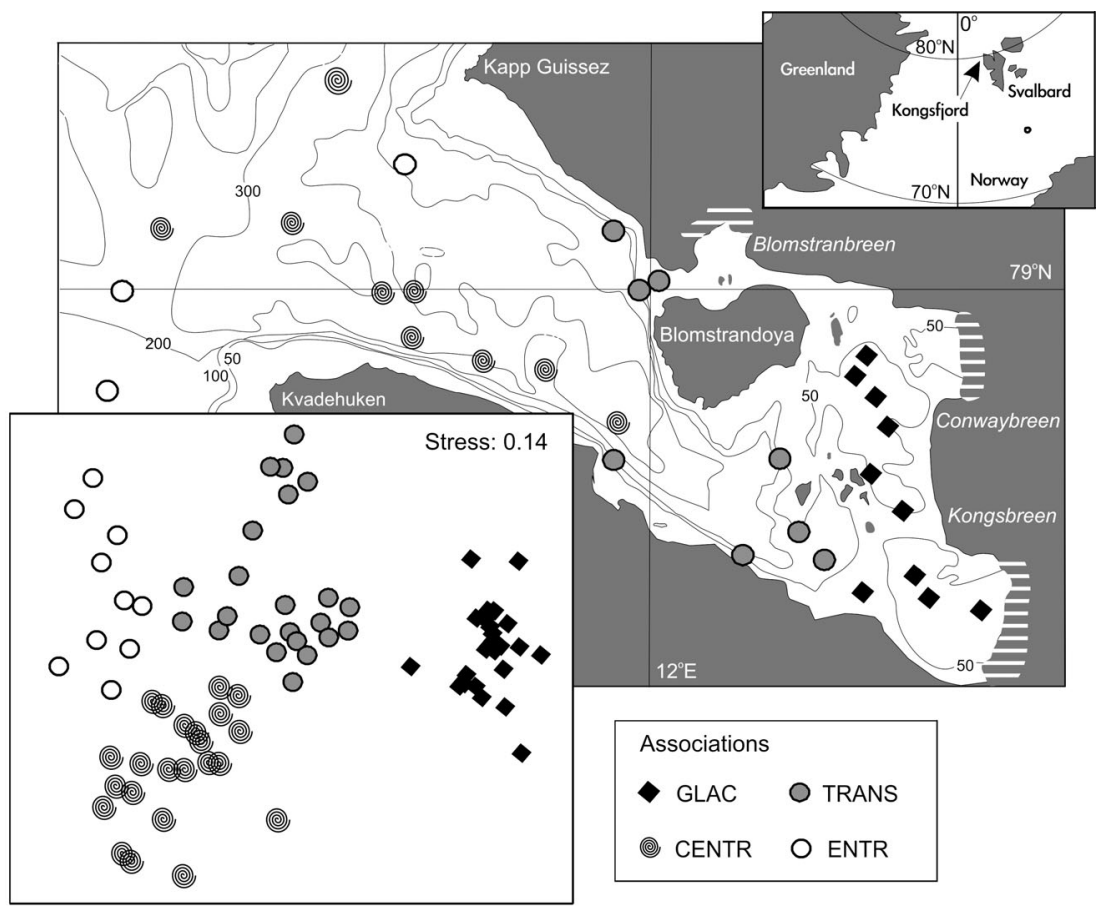

Fig. 1. Location of sampling stations in Kongsfjord. The symbols represent 4 associations (GLAC, TRANS, CENTR and ENTR) based on multiple samples taken at sampling stations. The results of non-metric multidimensional scaling of Bray-Curtis similarities of 4th-root transformed species abundances in samples are presented in the lower inset in the study area map. The hatched areas represent the tidal glacier fronts

bay $\left(20000 \mathrm{~g} \mathrm{~m}^{-2} \mathrm{yr}^{-1}\right)$ to the central part of the fjord (1800 to $3800 \mathrm{~g} \mathrm{~m}^{-2} \mathrm{yr}^{-1}$ ) and, again, by another order of magnitude towards the outer fjord $\left(200 \mathrm{~g} \mathrm{~m}^{-2} \mathrm{yr}^{-1}\right.$; Svendsen et al. 2002). In glacial bays the deposited material is not compacted and the water content in surface sediments is high (A. Zaborska pers. comm.). The combination of high sedimentation, iceberg scour, frequent sediment slides and gravity flows results in the formation of unconsolidated, easily eroded sediments (Dowdeswell 1987, Syvitski et al. 1987), and the stability of the sediments decreases the closer one gets to the glaciers. The stability of the sediments in different parts of Kongsfjord both influences and is influenced by the benthic fauna. In the glacial bay the fauna is dominated by mobile protobranch bivalves, which are known to destabilize the sediment, while in the outer basin the fauna is dominated by large, tube-dwelling polychaetes, which stabilize sediment (WlodarskaKowalczuk \& Pearson 2004).

The organic carbon content in the sediments decreases from $>2.5 \mathrm{mg} \mathrm{g}^{-1}$ at the fjord mouth to $<0.2 \mathrm{mg} \mathrm{g}^{-1}$ in the Kongsbreen glacial bay (Wlodarska-Kowalczuk \& Pearson 2004).

Sampling and data analysis. A total of 80 van Veen grab samples $\left(0.1 \mathrm{~m}^{2}\right)$ were taken from 30 stations in Kongsfjord at depths of 38 to 380 m (Fig. 1) in July 1997 and 1998 from RV 'Oceania', sieved (0.5 mm mesh), and the macrofauna extracted, counted and identified to the lowest possible taxon. The organisms were weighed, and the wet formalin biomass $(B)$ of each phylum was determined. Molluscs were weighed with shells, the polychaetes without tubes. The large anemone Cerianthus sp. was omitted from biomass estimates as its very high biomass and infrequent occurrence were likely to skew the data. The average individual biomass $(A I B)$ in each sample was calculated as biomass divided by abundance. AIB was used as an estimation of the average organism size in a sample.

Multivariate analyses were performed on a data matrix of species abundances in the samples to distinguish faunal associations. The similarities between samples were calculated using the Bray-Curtis index. Multidimensional scaling (MDS) of double-root transformed data for all samples was carried out. Such a transformation gives a 'balanced' view of community structure by reducing the influence of the numerically dominant species.

Differences in macrofauna density and $A I B$ between associations were identified using 1-way ANOVA. The normality of distribution of density and $A I B$ (as well as other metrics in the following analyses) in associations was tested with the use of the Shapiro-Wilk test and the homogeneity of variance with the use of the BrownForsyth test. Density and AIB were log-transformed prior to analyses to assess the normality of data distributions in associations and the homogeneity of variance. Post hoc comparative tests were carried out with the use of Fisher's least significant difference (LSD) tests. The differences in $B$ between associations were tested using the non-parametric Kruskal-Wallis test, as even after transformations of data the homogeneity of variance could not be assessed. Post hoc testing was carried out with the use of pair-wise Mann-Whitney $U$-tests.

Each of the 4 associations described below were found over a range of depths. The association GLAC ( 38 to $83 \mathrm{~m}$ ) and TRANS ( 72 to $125 \mathrm{~m}$ ) were composed of samples taken in shallower sites than CENTR (258 to $380 \mathrm{~m}$ ) and ENTR (155 to $258 \mathrm{~m}$ ). To find out if the studied metrics were related to depth, we carried out the analyses of model I linear regression of density, $B$ and AIB to depth.

Species richness defined as the total number of species in a sample $(S)$, species diversity measured using the Hurlbert index calculated for 100 individuals 
(ES[100]) and the Shannon-Wiener $\log _{\mathrm{e}}$-based index $\left(H^{\prime}\right)$ were calculated. The evenness (equitability) of distribution of individuals between species was calculated as the Pielou index $(J)$. The differences in $S, E S[100], H^{\prime}$ and $J$ between the associations were tested using one-way ANOVA. $S$ and $H^{\prime}$ were logtransformed prior to analysis to assess the normality of data distributions in associations and the homogeneity of variance. Fisher's LSD tests were used for post hoc multiple comparisons. The relationship of $S, E S[100]$, $H^{\prime}$ and $J$ to depth was investigated using model I linear regression.

To explore the taxonomic diversity of samples, 2 measures of taxonomic distinctness were calculated: AvTD (average taxonomic distinctness of presence/ absence data) and varTD (variation in taxonomic distinctness) (Clarke \& Warwick 2001). The taxonomic diversity measures differ from other metrics of species richness and species diversity in that they include information on the taxonomic position of species. AvTD describes the average taxonomic distance (the 'path length' between 2 species following Linnean taxonomy) of all species in an association. varTD is defined as the variance of the taxonomic distances between all pairs of species in the association. Six taxonomic levels were used in calculations: species, genus, family, order, class and phylum, and equal step levels between successive taxonomic levels were assumed. Differences between associations were identified using 1-way ANOVA for varTD and the nonparametric Kruskal-Wallis test for AvTD (as the homogeneity of variance could not be assessed even after data transformations). Post hoc testing was carried out using Fisher's LSD tests and Mann-Whitney $U$-tests.

The diversity of functional groups (guilds) was analysed. All species were classified by their feeding mode and comparative mobility according to Fauchald \& Jumars (1979), Feder \& Matheke (1980) and unpublished observations. Fifteen guilds representing combinations of 5 feeding types - carnivores, herbivores, suspension feeders, surface detritus feeders, subsurface detritus feeders (burrowers) - and 3 mobility types - sessile, discretely mobile, mobile - were considered. The number of guilds and percentage of each functional group in the total number of organisms were calculated.

$\alpha$ and $\beta$ diversities represent 2 different aspects of diversity measurements. $\alpha$ diversity is diversity of a defined spatial unit-in our case species richness, species diversity, taxonomic distinctness or functional group diversity of a sample. $\beta$ diversity does not measure the diversity of the spatial unit itself but the extent to which the diversity of 2 or more spatial units differ, i.e. the spatial heterogeneity of the association (Magurran 2004). Here we applied 3 categories of $\beta$ diversity measures (Magurran 2004).
(1) $\beta_{W}$ : a measure of the extent of the difference between $\alpha$ diversity of several spatial units in relation to the $\gamma$ diversity (regional diversity) (Whittaker 1972). When treating species richness in associations as $\gamma$ diversity, we calculated $\beta_{w}$ for each association as $\beta_{w}=$ $(\gamma / \alpha)-1$, where $\alpha$ is an average number of species in a sample and $\gamma$ is total number of species in the association.

(2) $C$ : complementarity (or 'biotic distinctness') - the percentage of all species in 2 samples, which occur in only one or the other of them (= are 'complementary') (Colwell \& Coddington 1994). C may vary from $0 \%$ (identical species lists) to $100 \%$ (completely distinct species lists). We calculated it using EstimateS (V.7.5, R. K. Colwell, http://purl.oclc.org/estimates). The differences in $C$ between the associations were identified using the non-parametric Kruskal-Wallis test (the homogeneity of variance could not be assessed even after transformations of data). Pair-wise Mann-Whitney $U$-tests were used for post hoc multiple comparisons.

(3) Species accumulation plots which exploit the turnover related to the accumulation of species with increased sampling area (Magurran 2004). The curvilinear plots show the cumulative number of different species observed as each new sample is added, the curves being averaged over 999 permutations of randomly ordered samples.

The Index of Multivariate Dispersion (IMD) of Warwick \& Clarke (1993) is an expression of multivariate variance among samples. IMD was calculated for associations to quantify the differences in faunal variability between associations. The increased variability among samples was proposed as one of the diagnostic features of disturbed communities (Warwick \& Clarke 1993). The relative variability between groups of samples can be expressed in a relative dispersion $R S$ sequence in which the larger values correspond to greater withingroup dispersion (Clarke \& Warwick 1994). The IMD compares average ranks of similarities among samples in 2 groups of samples and can range from +1 (all similarities among samples in one group are lower than any similarities in the other one) to -1 (no differences between groups).

All data analyses were carried out using the PRIMER Package (Clarke \& Warwick 1994) and the Statsoft software STATISTICA v.6.

\section{RESULTS}

Four faunal associations located along the fjord axis were distinguished: (1) GLAC, including stations situated in the inner glacial bay in proximity to the Kongsbreen and Conwaybreen glaciers; (2) TRANS, including stations situated close to the Lovenoyane islands 
next to the Kongsbreen glacial bay, or close to Blomstrandbreen, a less active glacier terminating in the middle of the fjord ( ) CENTR, including stations situated in the central and outer parts of the fjord; (4) ENTR, including stations situated at the entrance of the fjord (Fig. 1). The details of the distribution and species composition of these associations as well as the results of more detailed multivariate analyses (including clustering of samples and application of different transformations of data) are described by WlodarskaKowalczuk \& Pearson (2004).

There were significant differences between the various associations in density, $B$ and $A I B$ (ANOVA $F=$ 8.22, $\mathrm{p}<0.001$ for density, $F=8.18, \mathrm{p}<0.001$ for $A I B$, Kruskal-Wallis test $H=13.30, \mathrm{p}<0.01$ for $B$ ). There were significant differences ( $p<0.05$, Fisher's LSD) in density for all pairs of associations except for the GLAC-CENTR pair. Mean density was the highest in samples of the TRANS association, lower in the GLAC and CENTR associations, and lowest in the ENTR association (Table 1). Mean $B$ and $A I B$ were lower in the GLAC association than in the other associations (Table 1). Post hoc multiple comparisons showed that $B$ was significantly different only for the pairs GLAC-TRANS and TRANS-CENTR (Mann-Whitney $U$-test, $\mathrm{p}<0.05)$, while $A I B$ was significantly different in the pairs GLAC-TRANS, GLAC-ENTR, TRANSENTR and CENTR-ENTR. There was no significant relationship between density, $B$ or $A I B$ and depth (model I linear regression: $\mathrm{p}=0.15,0.68,0.65$ respectively).

Two main patterns of distribution were found among the 12 most numerous species in the fjord. Some occurred mainly in the GLAC and TRANS associations (the bivalve Yoldiella solidula and polychaetes of the Chaetozone group, Chone paucibranchiata and Cossura longocirrata), while others occurred only in the TRANS, CENTR and ENTR associations (the polychaetes Lumbrineris sp., Leitoscoloplos sp., Levinsenia gracilis, Maldane sarsi and Heteromastus filiformis) (Fig. 2). Individuals of the bivalve species Axinopsida orbiculata and Y. lenticula and the polychaete Prionospio sp. were located mainly in one association (Fig. 2).

There were significant differences between associations in all species richness and species diversity indices used (ANOVA $F=32.15, \mathrm{p}<0.001$ for $S, F=$ 77.52, $\mathrm{p}<0.001$ for $H, F=96.90, \mathrm{p}<0.001$ for $E S$ [100] and $F=22.43, \mathrm{p}<0.001$ for $J$ ). There were significant differences ( $p<0.05$, Fisher's LSD) in these metrics for all pairs of associations except for TRANS-ENTR and CENTR-ENTR for $S$ and TRANS-ENTR for $H$ and $J . S$,
$H, E S[100]$ and $J$ were lowest in the GLAC association (respectively $22.2 \pm 5.6 \mathrm{SD}, 1.89 \pm 0.22 \mathrm{SD}, 12.8 \pm$ $2.2 \mathrm{SD}, 0.62 \pm 0.05 \mathrm{SD}$, Fig. 3$). S$ was highest in the TRANS association $(42.2 \pm 6.5 \mathrm{SD})$.

There was no significant relationship between $J$ and depth (model I linear regression, $\mathrm{p}=0.09$ ). The results of regression of $S, E S[100]$ and $H^{\prime}$ to depth were significant ( $\mathrm{p}<0.05)$, but the relationship was very weak $(\mathrm{R}=0.26,0.29$ and 0.25 respectively) - the regression to depth explains only 6 to $8 \%$ of the variation of these metrics $\left(r^{2}=0.07,0.08\right.$ and 0.06 respectively).

AvTD was highest while varTD was lowest in the GLAC association (Fig. 4). There were significant differences in these measures between associations (Kruskal-Wallis test $H=49.18, \mathrm{p}<0.001$ for AvTD, ANOVA $F=14.06, \mathrm{p}<0.001$ for $\operatorname{varTD})$. There were significant differences $(\mathrm{p}<0.05$, Mann-Whitney $U$ - test)

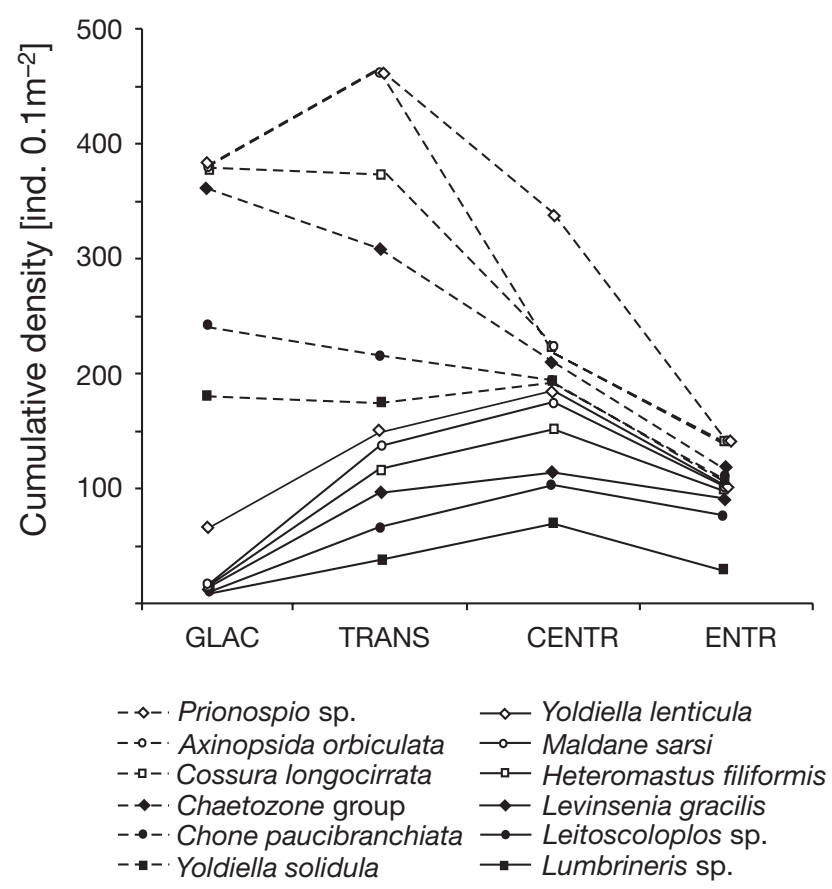

Fig. 2. Cumulative mean densities (ind. $0.1 \mathrm{~m}^{-2}$ ) in each association of the most abundant species in the fjord. Species with a dominance exceeding $2 \%$ are presented 

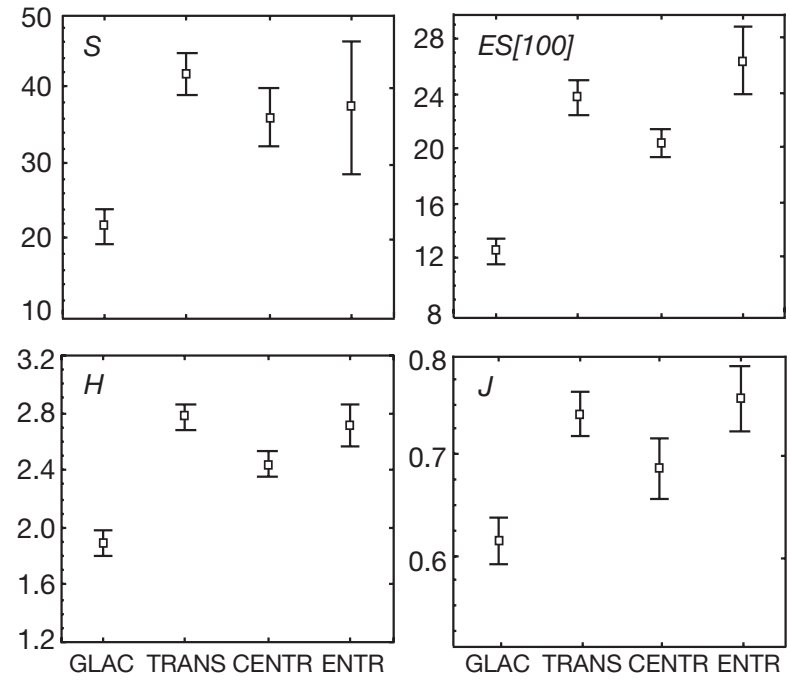

Fig. 3. Diversity in associations (mean and 95\% confidence intervals). $S$ : number of species per sample, ES [100]: Hurlbert index for 100 individuals, $H^{\prime}$ : Shannon-Wiener index, $J$ : Pielou evenness index
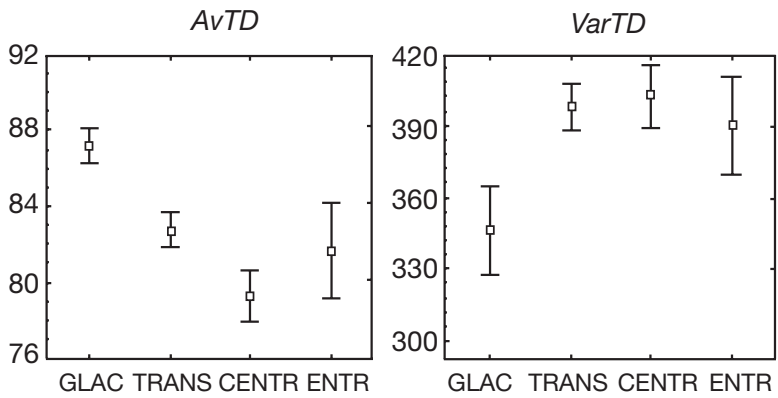

Fig. 4. Average taxonomic distinctness $(A v T D)$ and variance of taxonomic distinctness (varTD) in associations (mean and $95 \%$ confidence intervals)

in AvTD for all pairs of associations except TRANSENTR and CENTR-ENTR. There were significant differences $(\mathrm{p}<0.05$, Fisher's LSD) in varTD for GLAC-TRANS, GLAC-CENTR and GLAC-ENTR.

The number of functional groups was lowest in the glacial bay (11 groups, Table 2), while 14 to 15 occurred in other associations. The GLAC association was dominated by 1 guild-mobile surface-detritus feeders $(67 \%)$, while discretely mobile suspension/surface-detritus feeders comprised $13 \%$ of the fauna. Remaining guilds each accounted for $<5 \%$. In the TRANS, CENTR and ENTR associations, the most abundant guild accounted for around $30 \%$ of the fauna. In the TRANS association mobile surfacedetritus feeders made up $32 \%$ and mobile subsurface detritivores $22 \%$ of the assemblage. Mobile species capable of both suspension and deposit feeding made up 5 to $13 \%$ of the GLAC and TRANS associations but were poorly represented in the CENTR and ENTR associations. Mobile carnivores were well represented in the CENTR and ENTR associations (17 and 15\%, respectively) but less dominant in the TRANS and GLAC associations ( 7 and $4 \%$, respectively). The number of sedentary suspension feeders was highest in the TRANS and ENTR associations but low in the GLAC and CENTR areas. In general, the distribution of the fauna among the functional groups was more even in the TRANS, CENTR and ENTR associations than in the GLAC association.

$\beta_{w}$ was high both in the CENTR association (2.99) and in the GLAC association (2.61). It was lower in the TRANS association (2.13) and lowest in the ENTR association (1.77). $C$ was lowest in GLAC $(57.5 \pm 7.1)$ and increased towards the entrance of the fjord (59.6 \pm 7.3 in TRANS, $61.9 \pm 7.9$ in CENTR, $64.6 \pm 7.1$ in ENTR). There were significant differences between associations in $C$ (Kruskal-Wallis test $H=49.03$, p < 0.001 ). Post hoc multiple pair-wise testing showed significant differences between all pairs of associations ( $p<0.05$, Mann-Whitney $U$-test). None of the species accumulation curves stabilised towards asymptotic values (Fig. 5). The species accumulation curve representing the GLAC association was the least steep and lay below the curves representing other associations (Fig. 5).

The GLAC association samples were less scattered than samples of remaining associations on the MDS plot (Fig. 1). The $R S$ was much lower in the GLAC association (0.68) than in other associations (1.14 in

Table 2. Percentage of functional types in total number of animals in each association. Functional groups are designated by codes: first letter(s) = feeding type: $\mathrm{f}$ : suspension feeders, $\mathrm{s}$ : surface detritus feeders, b: subsurface detritus feeders, c: carnivores, o: omnivores; last letter $=$ mobility type: $\mathrm{m}$ : mobile, $\mathrm{d}$ : discretely mobile, s: sedentary; u: unknown functional type

\begin{tabular}{|lcccc|}
\hline $\begin{array}{l}\text { Functional } \\
\text { type }\end{array}$ & GLAC & TRANS & CENTR & ENTR \\
\hline $\mathrm{fs}$ & & & & \\
$\mathrm{fd}$ & 0.3 & 1.5 & 2.3 & 0.4 \\
$\mathrm{fm}$ & 0.1 & - & 0.1 & - \\
$\mathrm{f} / \mathrm{ss}$ & 0.3 & 0.4 & - & 4.7 \\
$\mathrm{f} / \mathrm{sd}$ & - & 0.1 & 1.0 & - \\
$\mathrm{f} / \mathrm{sm}$ & 13.1 & 4.9 & 1.3 & 0.6 \\
$\mathrm{ss}$ & 6.7 & 11.1 & 0.1 & 1.4 \\
$\mathrm{sd}$ & 0.7 & 8.7 & 1.6 & 8.4 \\
$\mathrm{sm}$ & - & 0.4 & 30.2 & 1.7 \\
$\mathrm{bs}$ & 66.6 & 32.4 & 9.2 & 12.2 \\
$\mathrm{bm}$ & - & 4.0 & 10.3 & 3.9 \\
$\mathrm{~cm}$ & 4.4 & 21.7 & 22.0 & 34.4 \\
$\mathrm{c} / \mathrm{bm}$ & 3.5 & 7.4 & 17.0 & 14.9 \\
$\mathrm{~s} / \mathrm{cm}$ & - & 1.1 & 0.8 & 1.3 \\
$\mathrm{om}$ & 1.4 & 1.3 & 1.1 & 9.4 \\
$\mathrm{u}$ & - & 0.1 & 0.2 & 0.6 \\
& 2.9 & 4.9 & 2.7 & 6.3 \\
\hline
\end{tabular}




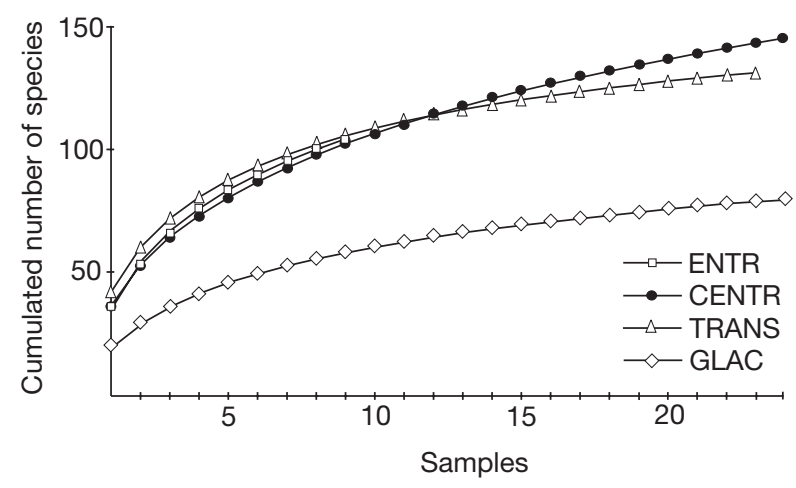

Fig. 5. Species accumulation curves for associations

TRANS and CENTR, 1.43 in ENTR). The IMD also showed that the dispersion was lower (and the withingroup similarity higher) in GLAC than in all other associations (Table 3).

\section{DISCUSSION}

The disturbance caused by the Kongsbreen glacier resulted in clear patterns of change in the benthic fauna. Four faunal associations were located along the gradient of the glacial disturbance/increasing distance from the glaciers. In areas with high disturbance, the fauna was dominated by small-bodied surface-depositfeeding species with low biomass and low diversity. As distance from the glacier increased, both biomass and diversity increased and the trophic structure became more complex. The near-glacier association (GLAC) consisted of the shallowest stations, while the outermost association (ENTR) was located in the deepest part of the fjord, so the depth was initially considered as a potentially confounding variable in the interpretation of our results. However, regression analysis indicated that the patterns of change in the macrofauna were unrelated to depth, while the differences between associations were very clear $(p<0.001)$, strongly suggesting that the patterns that we observed were more likely to be related to distance from the glacier and hence to the level of glacial disturbance.

Table 3. Index of Multivariate Dispersion (IMD) between pairs of associations

\begin{tabular}{|ll|}
\hline Associations compared & IMD \\
\hline GLAC/CENTR & -0.476 \\
GLAC/TRANS & -0.451 \\
GLAC/ENTR & -0.701 \\
CENTR/TRANS & -0.019 \\
CENTR/ENTR & -0.331 \\
TRANS/ENTR & -0.304 \\
\hline
\end{tabular}

The highest faunal density in Kongsfjord was noted in the TRANS association - the second in a series of associations along the glacier-derived disturbance gradient. In Pearson \& Rosenberg's (1978) organic enrichment gradient model, the maximum abundance of the macrofauna was also found at a short distance from the area of maximum disturbance. In this model a small number of opportunistic species colonised organically enriched sediments and became extremely abundant in areas immediately beyond the area of maximum pollution. In these locations the environmental conditions were sufficiently harsh to exclude other competing species. In Kongsfjord the maximum density in the TRANS association was also consistent with its transitional character. The species dominating in the glacial bay, mostly small mobile bivalves and polychaetes adapted to high mineral sedimentation and unstable sediments, remained abundant in the TRANS association but then either disappeared or diminished greatly as one gets closer to the fjord mouth. On the other hand, the TRANS association also included high densities of species, often large tube-dwelling polychaetes, which were dominant in the central part of the fjord but absent in the dynamic environment close to the glacier.

Disturbance gradients are often accompanied by a decrease in benthic biomass, e.g. in areas severely disturbed by fish trawling (Jennings et al. 2001), increased fluvial sedimentation (Aller \& Stupakoff 1996), deepsea nodule mining (Ingole et al. 2001) and organic enrichment (Pearson \& Rosenberg 1978). In an Arctic fjord, the low biomass in areas near glaciers may result both from physical disturbance and the low quantities of available organic matter (Gorlich et al. 1987).

Disturbed areas are usually colonised by surfacedwelling organisms that are restricted to the sediment-water interface (e.g. Pearson \& Rosenberg 1978, Rhoads et al. 1978, Aller \& Stupakoff 1996, Kaiser et al. 2000). Large-bodied, deeply penetrating and effective bioturbators, which often act as structural species by maintaining spatial complexity, are often eliminated (Widdicombe et al. 2004). Mean average individual biomass $(A I B)$ was lowest in the glacial bay as the GLAC association was composed of organisms smaller than those found in associations situated further from the glacier. The organisms' size and depth of sediment penetration as well as the complexity of the physical structure of the community decrease the closer one gets to the glacier (Wlodarska-Kowalczuk \& Pearson 2004). Small mobile bivalves and polychaetes, which stay on or close to the sediment surface, dominate the glacial bay fauna. The central basin associations include large tube-dwelling, deeply burrowing polychaetes - structural species such as Spiochaetopterus typicus or Maldane sarsi. They are accompanied by 
small tube dwellers and a variety of mobile species of different sizes freely burrowing in the sediment or staying at the surface (Wlodarska-Kowalczuk \& Pearson 2004).

In pollution impact studies, the small, abundant species colonising disturbed sediments are usually opportunists sensu Grassle \& Grassle (1974). The 'peak of opportunists' was reported for sites impacted by organic pollution (Pearson \& Rosenberg 1978), for sediments deprived of benthic fauna by acute, catastrophic disturbance as with intensive mine tailings discharge (Olsgard \& Halse 1993) or after manipulated defaunation of sediments in experimental studies (McCall 1977). Kendall et al. (2003) stated that none of the species dominating in the Kongsfjord glacial bay could be classified as truly opportunistic species. For example, Chaetosone setoza was reported to have lecithotrophic development in Arctic waters (Curtis 1977). The larval shells of Yoldiella solidula, Y. lenticula and Thyasira dunbari also suggest that these species have a lecithotrophic mode of dispersal (A. Warén pers. comm.). The other dominants are known to brood the low numbers of offspring they produce (Kendall et al. 2003); such traits do not fit the classical definition of an opportunist. It appears that species dominating in nearglacial sites are better adapted to resist disturbance rather than to respond to disturbance by employing special life-history traits. A classical successional shift from 'opportunistic' to 'equilibrium' species was observed neither in areas exposed to high rates of inorganic sedimentation resulting from mine tailings discharge (Lancellotti \& Stotz 2004) nor along a gradient of chronic physical disturbance caused by 'benthic storms' in the deep sea (Aller 1997). The nature of disturbance described by Aller (1997) is similar in many respects to that in the glacial bays as it is abiotic, natural and chronic, influencing sediment stability and sedimentary deposition in the near-bottom water layers, as well as being accompanied by a low input of organic matter.

The dynamic equilibrium hypothesis states that diversity is maintained by the equilibrium between mortality-causing disturbances and rate of competitive displacement, the latter depending on the growth rates of populations (Huston 1979). In the glacial bay the loading of mineral material induces both a high intensity of disturbance and low primary productivity. With a low intensity of disturbance the low productivity results in a low rate of competitive displacement, and thus the high diversity is maintained. With a high intensity of disturbance, the low productivity has the opposite effect - the diversity is even more depressed (Huston 1994). In Kongsfjord, the glacier-induced disturbance was accompanied by a decrease both in species number and in evenness of the distribution of individuals among the species. The few disturbancetolerant species dominated the glacial bay community. Experimental evidence indicated that the deposition of a layer as thin as $3 \mathrm{~mm}$ of terrigenous sediments was sufficient to reduce the number of species in a soft sediment benthic community, and the rare species were eliminated first (Lohrer et al. 2004). In Kongfsjord the number of species was highest in a 'transition zone' (the TRANS association), where the fauna consisted of species of both adjacent communities, a pattern consistent with the predictions of the IntermediateDisturbance Hypothesis (Huston 1979). The intermediate levels of bioturbation increase benthic diversity as the depth of oxygenated layers, and thus the effective volume of substrate, is higher in bioturbated sediments (Widdicombe et al. 2004). The intermediate levels of physical disturbance of sediments in an Arctic fjord promote the co-existence of tube-building sedentary polychaetes (dominating in the CENTR association) and mobile detritus-feeding bivalves and polychaetes (dominating in the GLAC association, WlodarskaKowalczuk \& Pearson 2004), which are likely to compete for space and food in stable conditions (Wilson 1991).

The decrease in species diversity as one approaches the glacier is consistent with patterns described for different disturbance gradients. Surprisingly, taxonomic distinctness did not follow that trend; it was highest in the glacial bay and its variance was lowest there, i.e. species were evenly distributed across the hierarchical taxonomic tree (Warwick \& Clarke 2001). In several cases a decrease in taxonomic distinctness and increase in its variance followed events of anthropogenic disturbance, or environmental deterioration (Warwick \& Clarke 1995, Warwick et al. 2002), even if the species diversity indices remained constant or even increased. For this reason it has been proposed as a very sensitive method for detecting disturbances and environmental changes. Its usefulness in disturbance studies has been promoted on the basis that 'in grossly perturbed situations communities are maintained in an early stage of succession and often comprise guilds of closely related sibling species' (Warwick \& Clarke 2001). Some cases have been reported where taxonomic distinctness measures did not show the effect of severe environmental contamination (Somerfield et al. 1997), thus raising doubts about the universal applicability of taxonomic distinctness indices in the detection of disturbance effects. In the disturbed environment of the glacial bay we obviously do not have a small set of closely related species; instead we have a taxonomically diverse group of species well adapted to the environment in which they live. This difference from classical disturbance assemblages may stem from the 'longer history' of this natural disturbance compared to 
relatively 'recent' anthropogenic disturbances or the 'chronic' and 'predictable' character of disturbance in the glacial bay, in contrast to many anthropogenic events of more 'episodic' and 'unpredictable' character. That might allow several unrelated groups of animals to find their ways to adapt.

Functional group diversity may be a better determinant of ecosystem function than species richness. In Kongsfjord, both biodiversity metrics and trophic complexity become higher with distance from the glacier, agreeing well with other studies. The simplification of functional structure in disturbed communities has been described for cases of organic pollution (Pearson \& Rosenberg (1978) and dredge disposal (Rhoads et al. 1978). Bonsdorf \& Pearson (1999) noted a decrease in the number of trophic groups along a gradient of disturbances connected with lowered salinity in the Baltic Sea. Even if the identity of the dominant guild differs in cases of organic pollution (mobile tubiculous subsurface detritus feeders, Pearson \& Rosenberg 1978) or dredge disposal (tube-dwelling surface-detritus feeders, Rhoads et al. 1978) from those in the glacial bay (mobile surface-detritus feeders), the decrease in functional group diversity in disturbed communities is similar in all cases. In areas not experiencing the disturbance, the simple, 'pioneer' communities with simpler benthic infaunal food webs dominated by one functional group are replaced by more complex communities composed of animals from a wide range of size and functional types, presumably exploiting more resource niches (creating more complex food webs).

The relation between benthic variability and beta diversity and disturbance is unclear. In the glacial bay the $\beta$ diversity and faunal dispersion was lower than in other parts of the fjord. Kendall et al. (2003) studied multiscale patterns of species turnover in a northern part of the Kongsfjord glacial bay. They found the fauna in the inner basin of Kongsfjord to be very homogenous (50\% similarity between samples separated by $2 \mathrm{~km}$, and no difference in similarity between pairs of samples taken at the same station or $500 \mathrm{~m}$ apart). A comparison of species accumulation curves for Kongsfjord associations indicates that the pool of species in the glacial bay is relatively low. There are fewer species available to possibly vary among samples, and the variability is simply limited to some changes in the dominance pattern of a small set of dominants. Warwick \& Clarke (1993) presented several examples of increased variability of marine communities connected with increased level of perturbation. They proposed the IMD as a measure of community dispersion - a possible symptom of anthropogenic disturbance effects. However, no increase in variability, as expressed by the IMD or other measures, was observed in studies of effects of mine tailings discharge (Lancellotti \& Stotz 2004), organic pollution (Krassulya 2001), sewage discharge and waste dumping (Chapman et al. 1995, Stark et al. 2003).

\section{CONCLUSIONS}

We have presented a case of a high-latitude fjord in which chronic physical disturbance of natural origin is accompanied by low organic matter input. This combination affects benthic abundance (density, biomass) and diversity (species richness, evenness, taxonomic distinctness, functional and structural diversity, $\beta$ diversity) (Fig. 6). The benthic communities in nearglacier bays are dominated by small-bodied mobile surface-deposit feeders and characterised by low biomass, low species richness and low species diversity. A comparison of our data with published cases of various disturbances of different natural and anthropogenic

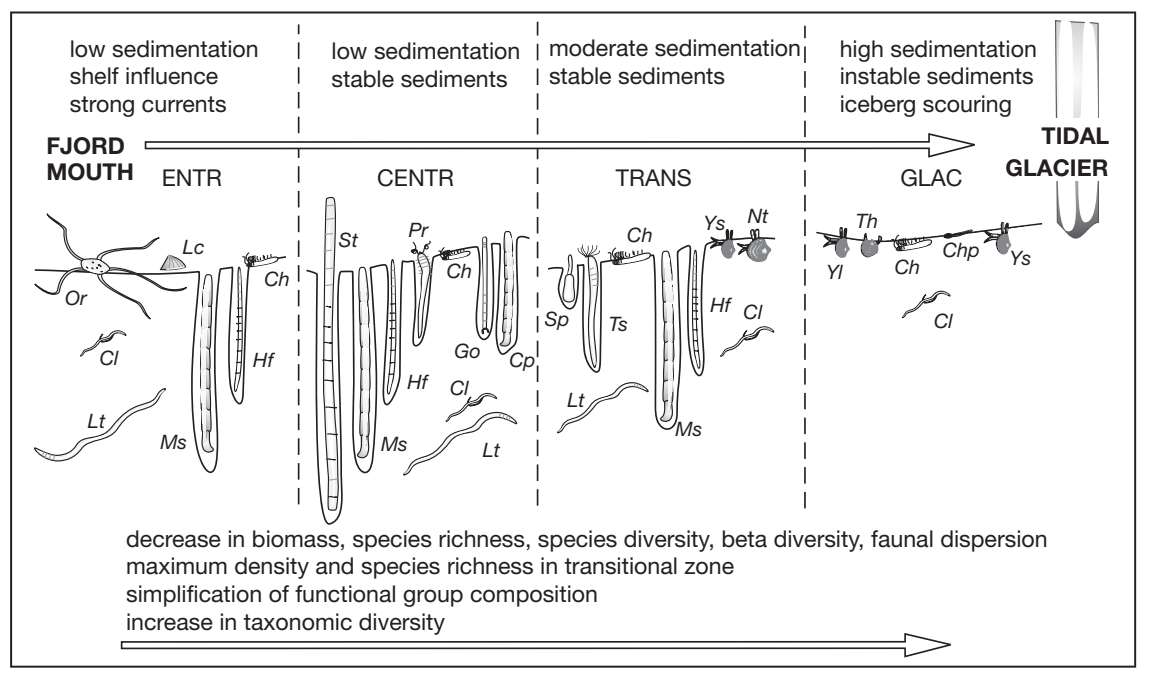

Fig. 6. Trends in macrobenthic abundance and diversity along a gradient of glacial disturbance. Dominants in Kongsfjord associations (according to Wlodarska-Kowalczuk \& Pearson 2004) include polychaetes (Chp: Chone paucibranchiata, Ch: Chaetozone group, Cl: Cossura longocirrata, Hf: Heteromastus filicornis, Ms: Maldane sarsi, Lt: Leitoscoloplos sp., Ts: Terebellides stroemi, Cp: Clymenura polaris, Go: Galathowenia oculata, Pr: Prionospio sp., St: Spiochaetopterus typicus), bivalves (Ys: Yoldiella solidula, Th: Thyasira dunbari, Yl: Yoldiella lenticula, Nt: Nuculoma tenuis), gastropods (Lc: Lepeta caeca), sipunculids (Sp: Sipunculida n. det.) and ophiuroids (Or: Ophiura robusta) 
origins indicates that the patterns of density, biomass, species richness, species diversity and functional group diversity are similar, regardless of the disturbance source. Even at the contrasting levels of organic matter input near the source of glacial disturbance and organic enrichment (Pearson \& Rosenberg 1978) the patterns in standing stock (decrease in biomass, the highest density in transitional zone) remain similar.

The trends in taxonomic distinctness, beta diversity and faunal dispersion are more variable and depend on the nature of the stress-generating factors. This suggests that the measures of taxonomic distinctness and faunal variability should be treated with more caution before being recommended as the universal diagnostic indicators of disturbance in benthic biota.

Acknowledgements. We thank Prof. J. M. Weslawski, Prof. H. M. Feder, Dr. M. Solan and Dr. P. Kuklinski for valuable comments and discussions. Dr. S. Thrush and 3 anonymous reviewers made comments which much improved the original manuscript. We thank Mr. S. Weslawski, who helped prepare Fig. 6. Support from the Polish National Committee for Scientific Research (Grant 3PO4F04722) and from the MARBEF Network of Excellence 'Marine Biodiversity and Ecosystem Functioning' which is funded in the Community's Sixth Framework Programme (contract no. GOCE-CT-2003-505446) is acknowledged.

\section{LITERATURE CITED}

Airoldi L (2003) The effects of sedimentation on rocky coast assemblages. Oceanogr Mar Biol Annu Rev 41:161-236

Aller JY (1997) Benthic community response to temporal and spatial gradients in physical disturbance within a deepsea western boundary region. Deep-Sea Res 44:39-69

Aller JY, Stupakoff I (1996) The distribution and seasonal characteristics of benthic communities on the Amazon shelf as indicators of physical processes. Cont Shelf Res 16:717-751

Blanchard AL, Feder HM, Shaw DG (2003) Variations in benthic fauna underneath an effluent mixing zone at a marine oil terminal in Port Valdez, Alaska. Mar Pollut Bull 46: 1583-1589

Bonsdorff E, Pearson TH (1999) Variation in the sublittoral macrozoobenthos of the Baltic sea along environmental gradients: a functional-group approach. Aust J Ecol 24:312-326

Chapman MG, Underwood AJ, Skilleter GA (1995) Variability at different spatial scales between a subtidal assemblage exposed to the discharge of sewage and 2 control assemblages. J Exp Mar Biol Ecol 189:103-122

Clarke A, Harris CM (2003) Polar marine ecosystems: major threats and future change. Environ Conserv 30:1-25

Clarke KR, Warwick RM (1994) Change in marine communities: an approach to statistical analyses and interpretation. Plymouth Marine Laboratory, Plymouth

Clarke KR, Warwick RM (2001) A further biodiversity index applicable to species lists: variation in taxonomic distinctness. Mar Ecol Prog Ser 216:265-278

Colwell RK, Coddington JA (1994) Estimating terrestrial biodiversity through extrapolation. Phil Trans R Soc Lond B 345:101-118

Curtis MA (1977) Life cycles and population dynamics of marine polychaetes from the Disko Bay area of West Greenland. Ophelia 16:9-58

Dowdeswell JA (1987) Processes of glaciomarine sedimentation. Prog Phys Geogr 11:52-90

Fauchald K, Jumars PA (1979) The diet of worms: a study of polychaete feeding guilds. Oceanogr Mar Biol Annu Rev 17:193-284

Feder HM, Matheke GEM (1980) Subtidal benthos. In: Colonell JW (ed) Port Valdez, Alaska: environmental studies 1976-1979. University of Alaska, Fairbanks, AK, p 235-324

Gorlich K, Weslawski JM, Zajaczkowski M (1987) Suspension settling effect on macrobenthos biomass distribution in the Hornsund fjord, Spitsbergen. Polar Res 5:175-192

Grassle JF, Grassle JP (1974) Opportunistic life histories and genetic systems in marine benthic polychaetes. J Mar Res 32:253-284

Hall SJ (1994) Physical disturbance and marine benthic communities: life in unconsolidated sediments. Oceanogr Mar Biol Annu Rev 32:179-239

Huston M (1979) A general hypothesis of species diversity. Am Nat 113:81-101

Huston MA (1994) Biological diversity: the coexistence of species on changing landscapes. Cambridge University Press, Cambridge

Ingole BS, Ansari ZA, Rathod V, Rodrigues N (2001) Response of deep-sea macrobenthos to a small-scale environmental disturbance. Deep-Sea Res II 48:3401-3410

Jennings S, Pinnegar JK, Polunin NCV, Warr KJ (2001) Impacts of trawling disturbance on the trophic structure of benthic invertebrate communities. Mar Ecol Prog Ser 213: $127-142$

Kaiser MJ, Ramsay CA, Richardson FE, Spence FE, Brandt AR (2000) Chronic fishing disturbance has changed shelf sea benthic community structure. J Anim Ecol 69:494-503

Kendall MA, Widdicombe S, Weslawski JM (2003) A multiscale study of biodiversity of the benthic infauna of the high-latitude Kongsfjord, Svalbard. Polar Biol 26:383-388

Krassulya N (2001) Choice of methodology for marine pollution monitoring in intertidal soft-sediment communities. CBM:s Skriftserie 3:131-148

Lancellotti DA, Stotz WB (2004) Effects of shoreline discharge of iron mine tailings on a marine soft-bottom community in northern Chile. Mar Pollut Bull 48:303-312

Lohrer AM, Thrush SF, Hewitt JE, Berkenbusch K, Ahrens M, Cummings VJ (2004) Terrestrially derived sediment: response of marine macrobenthic communities to thin terrigenous deposits. Mar Ecol Prog Ser 273:121-138

Mackey RL, Currie DJ (2001) The diversity-disturbance relationship: is it generally strong and peaked? Ecology 82: 3479-3492

Magurran AE (2004) Measuring Biological Diversity. Blackwell, Malden, MA

McCall P (1977) Community patterns and adaptive strategies of the infaunal benhos of Long Island Sound. J Mar Res 35: 221-264

Moore PG (1977) Inorganic particulate suspensions in the sea and their effects on marine animals. Oceanogr Mar Biol Annu Rev 15:225-363

Olsgard F, Hasle JR (1993) Impact of waste from titanium mining on benthic fauna. J Exp Mar Biol Ecol 172:185-213

Pearson TH, Rosenberg R (1978) Macrobenthic succession in relation to organic enrichment and pollution of the marine environment. Oceanogr Mar Biol Annu Rev 16:229-311

Rhoads DC, McCall PL, Yingst JY (1978) Disturbance and production on the estuarine seafloor. Am Sci 66:577-586

Rosenzweig ML (1995) Species diversity in space and time. Cambridge University Press, Cambridge 
Santos SL, Simon RJL (1980) Response of soft-bottom benthos to annual catastrophic disturbance in a South Florida estuary. Mar Ecol Prog Ser 3:347-355

Somerfield PJ, Olsgard F, Carr MR (1997) A further examination of 2 new taxonomic distinctness measures. Mar Ecol Prog Ser 154:303-306

Stark JS (1998) Heavy metal pollution and macrobenthic assemblages in soft-sediments in two Sydney estuaries, Australia. Mar Freshw Res 49:533-540

Stark JS, Riddle MJ, Simpson RD (2003) Human impacts in soft-sediment assemblages at Casey Station, East Antarctica: spatial variation, taxonomic resolution and data transformation. Austral Ecol 28:287-304

Svendsen JI, Elverhoi A, Mangerud J (1996) The retreat of the Barents Sea Ice Sheet on the western Svalbard Margin. Boreas 25:244-256

Svendsen H, Beszczynska-Møller A, Hagen JO, Lefauconnier $B$ and 11 others (2002) The physical environment of Kongsfjorden-Krossfjorden, an Arctic fiord system in Svalbard. Polar Res 21:133-166

Syvitski JPM, Burell CD, Skei JM (1987) Fjords: Processes and Products. Springer, New York

Syvitski JPM, Farrow GE, Atkinson RJA, Moore PG, Andrews JT (1989) Baffin Island fjord macrobenthos: bottom communities and environmental significance. Arctic 42: 232-247

Thrush SF, Hewitt JE, Cummings VJ, Ellis JI, Hatton C, Lohrer A, Norkko A (2004) Muddy waters: elevating sediment input to coastal and estuarine habitats. Front Ecol Environ 2:299-306

Warwick RM, Clarke KR (1993) Increased variability a symp-

Editorial responsibility: Otto Kinne (Editor-in-Chief),

Oldendorf/Luhe, Germany tom of stress in marine communities. J Exp Mar Biol Ecol 172:215-226

Warwick RM, Clarke KR (1995) New 'biodiversity measure reveal a decrease in taxonomic distinctness with increasing stress. Mar Ecol Prog Ser 129:301-305

Warwick RM, Clarke KR (2001) Practical measures of marine biodiversity based on relatedness of species. Oceanogr Mar Biol Annu Rev 39:207-231

Warwick RM, Ashman CM, Brown AR, Clarke KR and 6 others (2002) Inter-annual changes in the biodiversity and community structure of the macrobenthos in Tees Bay and the Tees estuary, UK associated with local and regional environmental events. Mar Ecol Prog Ser 234:1-13

Wheatcroft RA (2000) Oceanic flood sedimentation: a new perspective. Cont Shelf Res 20:2059-2066

Whittaker RH (1972) Evolution and measurements of species diversity. Taxon 21:213-251

Widdicombe S, Austen MC, Kendall MA, Olsgard F, Schaaning MT, Dashfield SL, Needham HR (2004) Importance of bioturbators for biodiversity maintenance: indirect effects of fishing disturbance. Mar Ecol Prog Ser 275:1-10

Wilson WH (1991) Competition and predation in marine soft-sediment communities. Annu Rev Ecol Syst 21: 221-241

Wlodarska-Kowalczuk M, Pearson TH (2004) Soft-bottom macrobenthic faunal associations and factors affecting species distributions in an Arctic glacial fjord (Kongsfjord, Spitsbergen). Polar Biol 25:155-167

Zajaczkowski M (2000) Doplyw i sedymentacja zawiesiny w wybranych fiordach zachodniego Spitsbergenu. PhD dissertation, Uniwersytet Gdanski, Gdynia (in Polish)

Submitted: November 30, 2004; Accepted: May 24, 2005

Proofs received from author(s): October 17, 2005 